\title{
Understanding Minoxidil-Induced Pericardial Effusion
}

\section{Ahmed M Shafter}

School of Medicine, University of California at Riverside UCR, Riverside, California, USA

*Corresponding author: Shafter AM, School of Medicine, University of California at Riverside UCR, Riverside, California, USA, Tel: 17734705417; E-mail: dr_shafter@yahoo.com

Received: Feb 22, 2018; Accepted: May 29, 2018; Published: May 31, 2018

Copyright: $\odot 2018$ Shafter AM. This is an open-access article distributed under the terms of the creative commons attribution license, which permits unrestricted use, distribution, and reproduction in any medium, provided the original author and source are credited.

\begin{abstract}
Minoxidil is a powerful antihypertensive medication that has been used extensively to control blood pressure in patients with renal failure. Its mechanism of action is through a cyclic AMP-mediated effect on arteriolar smooth muscle, with little effect on veins causing a direct vasodilatation of peripheral blood vessels. Minoxidil use has been associated with cause and/or exacerbation of pericardial effusions both in dialysis patients and those with normal kidney function. We report a 58-year-old African American female with history of severe resistant hypertension that has been controlled by Minoxidil $5 \mathrm{mg}$ po BID, and stage 3 chronic kidney disease who presented with shortness of breath, and headache. Blood pressure $240 / 124 \mathrm{mmHg}$. Her CT Brain revealed no intracranial bleed. Electrocardiogram showed normal sinus rhythm, with no ST/T wave changes. Cardiac biomarkers were normal. However, 2D Echocardiogram showed Estimated ejection fraction EF of $65 \%$, moderate pericardial effusion, with no evidence of pericardial tamponade, and moderate Left ventricular hypertrophy. This case reviews and explains the association between Minoxidil use and pericardial effusion, which may need appropriate treatment/monitoring, and extensive work ups to rule out other pathologies.
\end{abstract}

Keywords: Minoxidil; Resistant hypertension; Pericardial effusion

\section{Introduction}

Minoxidil is a direct-acting arterial vasodilator. Pericardial effusion is reported with minoxidil treatment both in patients undergoing dialysis and those with normal renal function. Pericardial effusion can be large and result in cardiac tamponade in some cases [1-4].

In this report, we describe a 58-year-old African American woman with moderate pericardial effusion diagnosed 12 months after starting Minoxidil for severe resistant hypertension that was completely resolved after discontinuing minoxidil.

\section{Case Presentation}

A 58-year-old African-American woman with past medical history of Hypertension and stage 3 chronic kidney disease, admitted with complaints of shortness of breath, and headache. She works as an accountant, denies tobacco, alcohol, and illicit drug use. She reports no past complaints of chest pain, dyspnea on exertion, paroxysmal nocturnal dyspnea, leg swelling, dizziness, palpitations, syncope, hemoptysis, fever, night sweats, weight loss, joint pain, skin rash, recent travel, or sick contact. She reports she ran out of minoxidil for the past 7 days.

In the emergency room, her blood pressure was $240 / 124 \mathrm{mmHg}$, pulse rate 78 beats/min regular, respiratory rate $24, \mathrm{SpO}_{2} 95 \%$ on room air, temperature $98.0^{\circ} \mathrm{F}\left(36.7^{\circ} \mathrm{C}\right)$, height $1.62 \mathrm{~m}$, weight $174 \mathrm{lb}(78.92$ $\mathrm{kg}$ ), BMI $30.07 \mathrm{~kg} / \mathrm{m}^{2}$. Physical examination was normal.

Electrocardiogram (ECG) showed normal sinus rhythm, no ST/T wave changes and left ventricular hypertrophy (Figure 1).

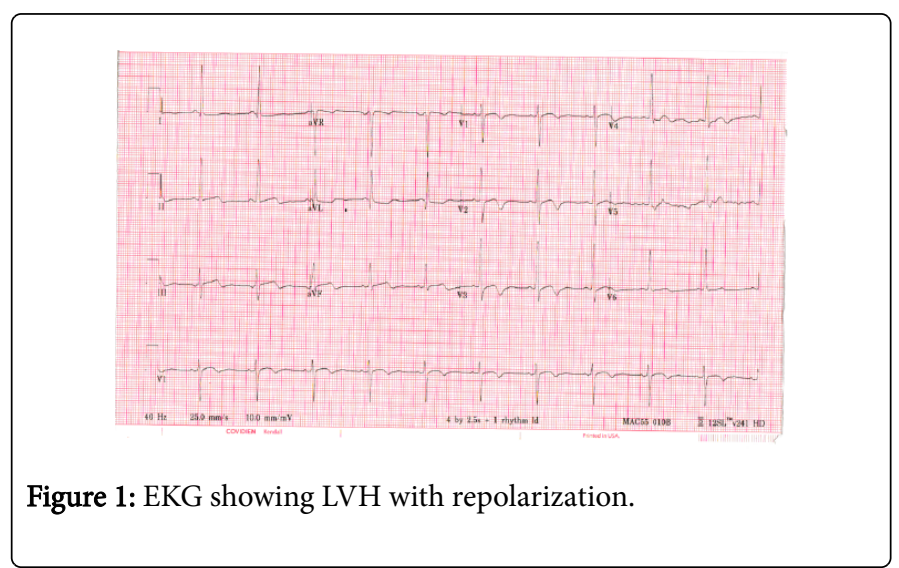

Chest radiograph (CXR) showed no acute cardiopulmonary pathology. Computed tomography of the Brain (CT Brain) was negative for intracranial hemorrhage.

2D Echocardiogram showed moderate pericardial effusion, with no evidence of pericardial tamponade. Estimated ejection fraction of $65 \%$, moderate Left ventricular hypertrophy. Estimated normal pulmonary systolic pressure, no mass, no thrombus, no wall motion abnormality, with normal valvular function (Figures 2- 7) (Table 1).

A diagnostic pericardiocentesis was performed with estimated 600 $\mathrm{ml}$ of straw colored fluid removed. Fluid study was negative for malignant cells, acid fast bacilli, with sterile culture. ANA, Anti smooth muscle Antibody, and Anti mitochondrial antibody were absent.

Minoxidil restarted with dose of $5 \mathrm{mg}$ po BID, and patient discharged home. A follow up 2D Echocardiogram was done 3 months later has revealed a recurrent small pericardial effusion. Minoxidil was discontinued, and Lasix $40 \mathrm{mg}$ po along with Metoprolol XL $50 \mathrm{mg}$ po daily and hydralazine $50 \mathrm{mg}$ po TID started. 2D Echocardiogram then 
repeated three months later showed complete resolution of pericardial effusion.

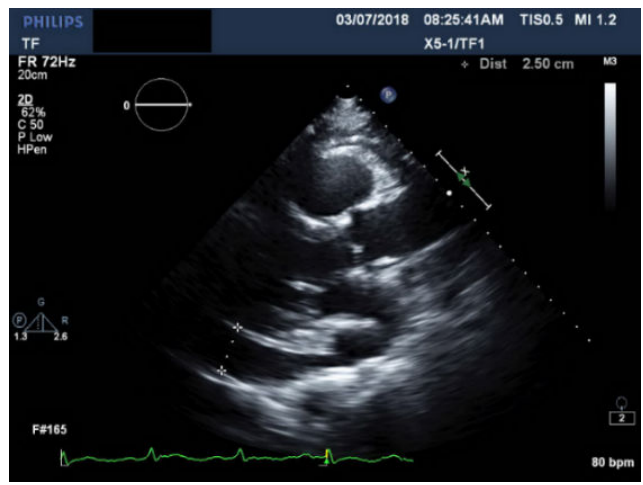

Figure 2: 2D Echo long axis view showing pericardial effusion.

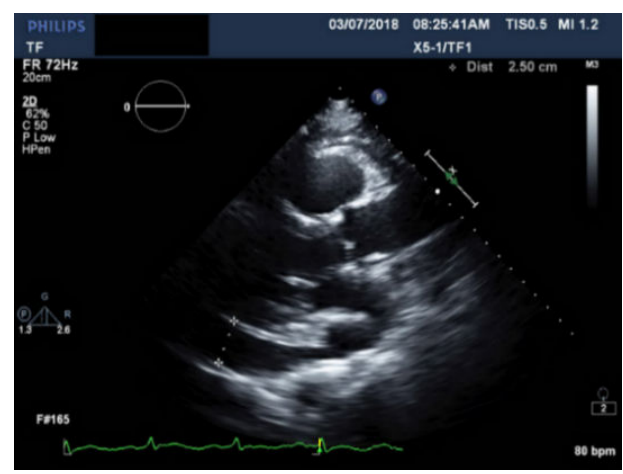

Figure 3: 2D Echo long axis view with doppler showing pericardial effusion.

\section{Discussion}

Minoxidil is a direct arterial vasodilator. It is a prodrug that is converted to its active form minoxidil sulfate by sulfation via the sulfotransferase enzyme SULT1A1. Its molecular structure is 6amino-1, 2-dihydro-1-hydroxy-2-imino-4-piperidinopyrimidine. Minoxidil acts by opening adenosine triphosphate-sensitive potassium channels in vascular smooth muscle cells.

Minoxidil is indicated only in the treatment of hypertension that is symptomatic or associated with end organ damage and is not controlled with maximum therapeutic doses of a diuretic plus two other antihypertensive drugs. It's contraindicated in pheochromocytoma.

The recommended initial dosage of Minoxidil is $5 \mathrm{mg}$ per day, it can be increased to $10 \mathrm{mg}, 20 \mathrm{mg}$ and $40 \mathrm{mg}$ in single or divided doses if required for optimum blood pressure control. The effective dosage range is usually 10 to $40 \mathrm{mg}$ per day. The maximum recommended dosage is $100 \mathrm{mg}$ per day.

Common side effects observed in minoxidil use are reflex tachycardia, rebound hypertension, increased cardiac output, decreased peripheral resistance mediated by baroreceptor stimulation, sodium and water retention, peripheral edema (7\%), pericardial effusion (3\%), heart failure, pericarditis, hypertrichosis. Minoxidil can also cause increased perfusion to the normal myocardium and decrease perfusion to the ischemic areas, which can result in angina and abnormal electrocardiogram $[5,6]$.

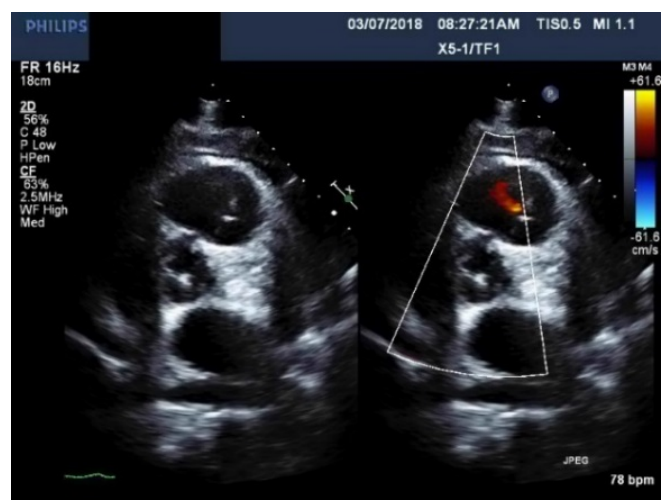

Figure 4: 2D Echo parasternal short axis showing aortic valve and evidence of pericardial effusion.

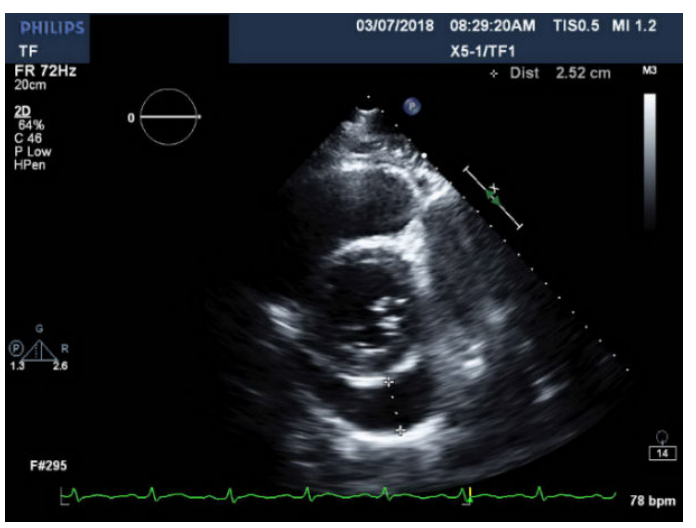

Figure 5: 2D Echo apical view showing pericardial effusion.

The exact mechanism of pericardial effusion in patients taking minoxidil is not clearly understood. It has been attributed to uremia, pericarditis as well as salt/water retention secondary to peripheral arterial dilatation. Our review of the literature shows that pericardial effusion although uncommon $3 \%$, it is commonly observed in patients with cardiac or renal disease $[4,7]$.

Minoxidil is predominantly arterial vasodilator with little venodilation effect; therefore, postural hypotension is not commonly observed in patient receiving minoxidil therapy. Minoxidil through its arteriolar vasodilation triggers carotid and aortic baroreceptor reflexes that subsequently stimulates peripheral sympathetic nervous system (SNS), which causes tachycardia, increase cardiac output and $\mathrm{O}_{2}$ demand, and increase in plasma renin activity, and biosynthesis of aldosterone that ultimately causes sodium/water retention [8-10].

Therefore, it is commonly given with therapeutic doses of $\beta$ blocker or a combined $\alpha-\beta$ blocker such as labetalol or carvedilol to prevent tachycardia and increased myocardial workload, along with loop diuretic to prevent serious fluid accumulation [3,5]. Our patient received only minoxidil without diuretic and $\beta$ blocker which could 
Citation: Shafter AM (2018) Understanding Minoxidil-Induced Pericardial Effusion. J Cardiovasc Dis Diagn 6: 323. doi: 10.4172/2329-9517.1000323

Page 3 of 4

explain the clinical presentation. Although pericardiocentesis is required in patients with hemodynamic compromise, most cases of pericardial effusion resolve spontaneously upon cessation of minoxidil therapy [11]. In our case, a recurrent pericardial effusion resolved completely after discontinuing minoxidil.

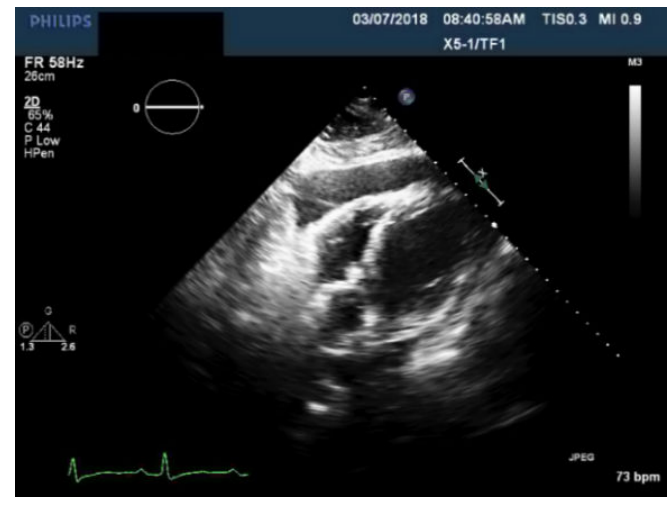

Figure 6: 2D Echo subxiphoid view showing evidence of pericardial effusion.

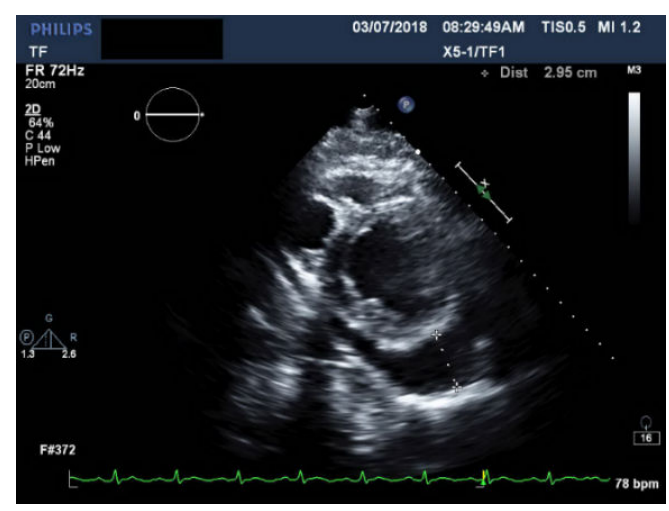

Figure 7: 2D Echo short axis view with evidence of pericardial effusion.

Our case demonstrates a pericardial effusion in a patient with resistant hypertension treated with Minoxidil. We believe, Minoxidil caused pericardial effusion through sodium/water retention, and through inducing pericarditis in a patient with renal impairment that subsequently resolved entirely after cessation of Minoxidil.

\section{Conclusion}

Minoxidil is a direct vasodilator introduced in the early 1970s for the treatment of hypertension. It is a potent medication used to control blood pressure in patients with severe resistant hypertension when other multidrug regimens failed to do so [1-4].

Minoxidil's common side effect is an increase in pulse rate and salt/ water retention. Therefore, minoxidil is commonly administered with both diuretic and $\beta$ blocker or combined $\alpha-\beta$ blocker such as labetalol or carvedilol to offset these side effects $[5,6,9]$. It must be administered under close supervision, and hypertension specialist should be involved.

\begin{tabular}{|c|c|c|}
\hline Labs & Results & Normal range \\
\hline WBC & $5.300 / \mathrm{microL}$ & $4.000-10,000 / \mathrm{microL}$ \\
\hline Haemoglobin $\mathrm{Hgb}$ & $12.8 \mathrm{~g} / \mathrm{dl}$ & $14-17 \mathrm{~g} / \mathrm{dl}$ \\
\hline НСТ & $38.40 \%$ & $41-51 \%$ \\
\hline MCV & $86 \mathrm{fL}$ & $80-100 \mathrm{fL}$ \\
\hline Platelets & 310,000/micro L & $150,000-350,000 /$ micro L \\
\hline INR & 1 & $0.9-1.1$ \\
\hline PTT & $28 \mathrm{~s}$ & $25-35 \mathrm{~s}$ \\
\hline Glucose & $94 \mathrm{mg} / \mathrm{dl}$ & $70-100 \mathrm{mg} / \mathrm{dl}$ \\
\hline Urea & $20 \mathrm{mg} / \mathrm{dl}$ & $8-20 \mathrm{mg} / \mathrm{dl}$ \\
\hline S. Creatinine & $1.3 \mathrm{mg} / \mathrm{dl}$ & $0.7-1.13 \mathrm{mg} / \mathrm{dl}$ \\
\hline GFR & $58 \mathrm{~mL} / \mathrm{min} / 1.73 \mathrm{~m} 2$ & $\begin{array}{l}90 \text { to } 120 \mathrm{~mL} / \mathrm{min} / 1.73 \\
\mathrm{~m} 2\end{array}$ \\
\hline Sodium & $142 \mathrm{meq} / \mathrm{L}$ & $135-145 \mathrm{meq} / \mathrm{L}$ \\
\hline Potassium & $3.8 \mathrm{meq} / \mathrm{L}$ & $3.5-5.0 \mathrm{meq} / \mathrm{L}$ \\
\hline S. Troponin I & $0.04-0.04-0.04 \mathrm{ng} / \mathrm{ml}$ & $0-0.5 \mathrm{ng} / \mathrm{ml}$ \\
\hline BNP & $478 \mathrm{pg} / \mathrm{ml}$ & $<100 \mathrm{pg} / \mathrm{ml}$ \\
\hline D. Dimer & $150 \mathrm{ng} / \mathrm{ml}$ & $<500 \mathrm{ng} / \mathrm{ml}$ \\
\hline Total cholesterol & $236 \mathrm{mg} / \mathrm{dl}$ & $150-199 \mathrm{mg} / \mathrm{dl}$ \\
\hline HDL & $24 \mathrm{mg} / \mathrm{dl}$ & $>40 \mathrm{mg} / \mathrm{dl}$ \\
\hline LDL & $188 \mathrm{mg} / \mathrm{dl}$ & $<130 \mathrm{mg} / \mathrm{dl}$ \\
\hline Triglycerides & $130 \mathrm{mg} / \mathrm{dl}$ & $<150 \mathrm{mg} / \mathrm{dl}$ \\
\hline A1C & $6.10 \%$ & $5.7-6.4 \%$ \\
\hline ESR & $10 \mathrm{~mm} / \mathrm{hr}$ & $0-22 \mathrm{~mm} / \mathrm{hr}$ \\
\hline CRP & $1.2 \mathrm{mg} / \mathrm{dl}$ & $<3.0 \mathrm{mg} / \mathrm{dl}$ \\
\hline ANA & 01:20 & 1: 40-1: 60 \\
\hline Rheumatoid factor RF & 18 units $/ \mathrm{ml}$ & $<40$ units $/ \mathrm{ml}$ \\
\hline ANCA & $<1: 20$ & $<1: 20$ \\
\hline $\mathrm{C} 3$ & $91 \mathrm{mg} / \mathrm{dl}$ & 88 to $206 \mathrm{mg} / \mathrm{dL}$ \\
\hline $\mathrm{C} 4$ & $51 \mathrm{mg} / \mathrm{dl}$ & 13 to $75 \mathrm{mg} / \mathrm{dL}$ \\
\hline $\begin{array}{l}\text { Anti mitochondrial } \\
\text { antibody AMA }\end{array}$ & $01: 23$ & $<1: 40$ \\
\hline $\begin{array}{l}\text { Anti smooth musle } \\
\text { antibody SMA }\end{array}$ & Negative & Negative \\
\hline $\begin{array}{l}\text { Viral Hepatitis } \\
\text { A, B, C }\end{array}$ & Nonreactive & Nonreactive \\
\hline HIV & Nonreactive & Nonreactive \\
\hline
\end{tabular}

Table 1: Details of laboratory values. 
Citation: Shafter AM (2018) Understanding Minoxidil-Induced Pericardial Effusion. J Cardiovasc Dis Diagn 6: 323. doi:

The incidence of pericardial effusion due to minoxidil is $\sim 3 \%$, and it resolves spontaneously after stopping the medication. Pericardiocentesis is usually not indicated unless there is hemodynamic instability.

\section{References}

1. Maisch B, Seferovic PM, Ristic AD, Erbel R, Rienmuller R, et al. (2004) Guidelines on the diagnosis and management of pericardial diseases executive summary: The task force on the diagnosis and management of pericardial diseases of the European society of cardiology. Eur Heart J 25: 587-610.

2. Houston MC, McChesney JA, Chatterjee K (1981) Pericardial effusion associated with minoxidil therapy. Arch Intern Med 141: 69-71.

3. Corey GR, Campbell PT, Van Trigt P, Kenney RT, O'Connor CM, et al. (1993) Etiology of large pericardial effusions. Am J Med 95: 209-213.

4. Sagrista-Sauleda J, Merce J, Permanyer-Miralda G, Soler-Soler J (2000) Clinical clues to the causes of large pericardial effusions. Am J Med 109: 95-101.

5. Franciosa JA, Jordan RA, Wilen MM, Leddy CL (1984) Minoxidil in patients with chronic left heart failure: Contrasting hemodynamic and clinical effects in a controlled trial. Circulation 70: 63-68.
6. National High Blood Pressure Education Program Working Group (2004) The fourth report on the diagnosis, evaluation, and treatment of high blood pressure in children and adolescents. Pediatrics 114: 555-576.

7. Go AS, Bauman MA, Coleman King SM, Fonarow GC, Lawrence W, et al. (2013) An effective approach to high blood pressure control: A science advisory from the American Heart Association, the American College of Cardiology, and the Centers for Disease Control and Prevention. Hypertension 63: 878-885.

8. James PA, Oparil S, Carter BL, Cushman WC, Dennison-Himmelfarb C, et al. (2014) 2014 evidence-based guideline for the management of high blood pressure in adults: Report from the panel members appointed to the Eighth Joint National Committee (JNC 8). JAMA 311: 507-520.

9. Levy PY, Corey R, Berger P, Habib G, Bonnet JL, et al. (2003) Etiologic diagnosis of 204 pericardial effusions. Medicine 82: 385-391.

10. Weber MA, Schiffrin EL, White WB, Mann S, Lindholm LH, et al. (2014) Clinical practice guidelines for the management of hypertension in the community: A statement by the American Society of Hypertension and the International Society of Hypertension. J Clin Hypertens 16: 14-26.

11. Ben-Horin S, Bank I, Shinfeld A, Kachel E, Guetta V, et al. (2007) Diagnostic value of the biochemical composition of pericardial effusions in patients undergoing pericardiocentesis. Am J Cardiol 99: 1294-1297. 